\title{
A proposed update for the classification and description of bacterial lipolytic enzymes
}

\author{
Thomas C A Hitch ${ }^{\text {Corresp., } 1 \text {, Thomas Clavel }}{ }^{1}$ \\ ${ }^{1}$ Functional Microbiome Research Group, Institute of Medical Microbiology, University hospital of RWTH Aachen, Aachen, Germany \\ Corresponding Author: Thomas C A Hitch \\ Email address: thitch@ukaachen.de
}

Bacterial lipolytic enzymes represent an important class of proteins: they provide their host species with access to additional resources and have multiple applications within the biotechnology sector. Since the formalisation of lipolytic enzymes into families and subfamilies, advances in molecular biology have led to the discovery of lipolytic enzymes unable to be classified via the existing system. Utilising sequence-based comparison methods, we have integrated these novel families within the classification system so that it now consists of 35 families and 11 true lipase subfamilies. Representative sequences for each family and subfamily have been defined as well as methodology for accurate comparison of novel sequences against the reference proteins, facilitating the future assignment of novel proteins. Both the code and protein sequences required for integration of additional families are available at:

https://github.com/thh32/Lipase_reclassification. 


\section{A proposed update for the classification and 2 description of bacterial lipolytic enzymes}

3 Thomas C. A. Hitch ${ }^{1, *}$ and Thomas Clavel ${ }^{1}$

4

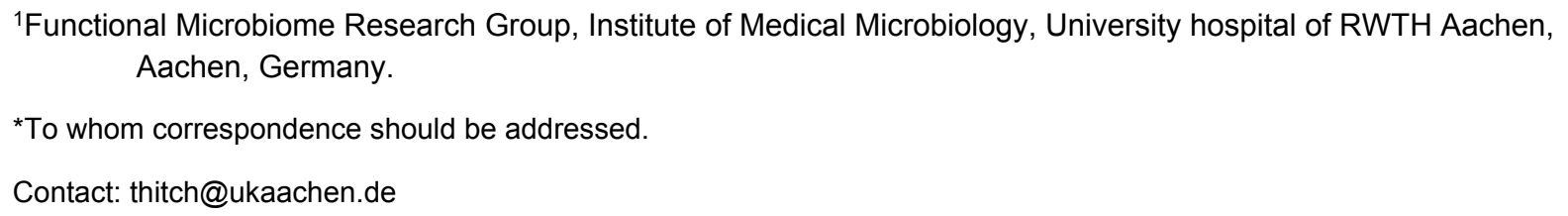

Abstract

Bacterial lipolytic enzymes represent an important class of proteins: they provide their host species with access to additional resources and have multiple applications within the biotechnology sector. Since the formalisation of lipolytic enzymes into families and subfamilies, advances in molecular biology have led to the discovery of lipolytic enzymes unable to be classified via the existing system. Utilising sequence-based comparison methods, we have integrated these novel families within the classification system so that it now consists of 35 families and 11 true lipase subfamilies.

Representative sequences for each family and subfamily have been defined as well as methodology for accurate comparison of novel sequences against the reference proteins, facilitating the future assignment of novel proteins. Both the code and protein sequences required for integration of additional families are available at: https://github.com/thh32/Lipase_reclassification

\section{Introduction}

Bacterial lipolytic enzymes are involved in a diverse range of microbial functions from metabolism of fat for energy (Drouault et al., 2002) to pathogenesis (Canaan et al., 2004). These enzymes are also of interest to the biotechnology industry for production of biodiesel and biopolymers (Jaeger \& Eggert, 2002). The alpha-beta hydrolase family contains both lipases (Enzyme commission (EC): 3.1.1.3) and carboxylesterases (EC: 3.1.1.1), both of which can catalyse the hydrolysis of 4-nitrophenyl-bound fatty acids (Guo et al., 2010; Rao et al., 2011). Lipases are defined as those which display some ability to catalyse the release of free fatty acids from long-chain triacylglycerols, such as those found in plant oil and animal fat, however activity may be highest against short or medium chain fatty acids (Jaeger \& Eggert, 2002; Levisson, van der Oost \& Kengen, 2007; Glogauer et al., 2011). This separates the lipases from the esterases, which may have activity against p-nitrophenyl (pNP)-bound fatty acids (a standard test for substrate specificity) but are unable to act upon triacylglycerol molecules (Yu et al., 2010; Masomian et al., 2016). A further subset of lipases are the true lipases which are defined as lipases which display preferential activity against long-chain fatty acids (>C10) (Sorokin \& Jones, 2009). The gold standard classification system of bacterial 
44 lipolytic enzymes was originally published by Arpigny and Jaeger in 1999 and defined

45 eight families based on the biochemical properties and sequence similarity of 53

46 proteins (Arpigny \& Jaeger, 1999).

47

48

49

50

51

52

53

54

55

56

57

58

59

60

61

62

63

64

65

66

67

68

69

70

71

72

73

74

75

76

77

78

79

80

81

82

83

84

85

86

87

88

89

Under the Arpigny and Jaeger (1999) classification system, true lipases were placed within a singular family (family I), within which sub-families are defined by unique lipase groups (Arpigny \& Jaeger, 1999; Jaeger \& Eggert, 2002). Originally, six subfamilies of true lipases were described based on shared features such as source genus, requirement of a chaperone for folding, motifs and sequence similarity (Arpigny \& Jaeger, 1999). Jaeger and Eggert (2002) redefined these families by splitting family I.5 into two new families, family I.5 and family I.6, and moving the previous members of family I.6 into family I.7 (Jaeger \& Eggert, 2002). In the 20 years since this bacterial lipolytic enzyme classification system was published, more than twice as many 'novel' families have been proposed (Handrick et al., 2001; Ewis, Abdelal \& Lu, 2004; Lee et al., 2010, 2006; Levisson, van der Oost \& Kengen, 2007; Bender et al., 2009; Kim et al., 2009; Hu et al., 2010; Rao et al., 2011; Jeon et al., 2011; Bassegoda, Pastor \& Diaz, 2012; Charbonneau \& Beauregard, 2013; Zarafeta et al., 2016; Castilla et al., 2017; Parapouli et al., 2018). A recent update to this system expanded the system to include some (11 of 30) of the recently published novel lipases within 19 families and 8 true lipase sub-families, however many lipolytic proteins remain unclassified (Kovacic et al., 2019).

Many claims of identifying novel families of lipolytic enzymes have been made, however no exhaustive comparison has been conducted to verify and combine these results. This has led to an inconsistent characterisation system and multiple publications claiming discovery of the same family (Parapouli et al., 2018). Examples of this are family X (Levisson, van der Oost \& Kengen, 2007; Bassegoda, Pastor \& Diaz, 2012) and family XV (Charbonneau \& Beauregard, 2013; Zarafeta et al., 2016), both of which have been coined twice. Rao et al (2013) attempted to incorporate previously published families into their analysis, however their literature search did not include multiple families (Chu et al., 2008; Bender et al., 2009; Hu et al., 2010; Lee et al., 2010; Jeon et al., 2011; Nacke et al., 2011; Bassegoda, Pastor \& Diaz, 2012). Ferrer et al (2015) also attempted to integrate additional families into the Arpigny and Jaeger (1999) classification system. Both previous attempts at including additional families relied on the authors claims of 'novelty' without reanalysis of these claims and, as discussed above, incomplete literature searches mean additional 'novel' families have been missed from the analysis. The possibility exists that multiple publications may describe members of the same 'novel' family under different names, artificially inflating the number of families. Therefore, before additional families can be incorporated into the system and provided with a family number, previous claims of novelty must be confirmed and integration of these proteins into a singular classification system must occur.

Alternative classification systems for bacterial lipolytic enzymes have been published alongside online databases dedicated to these new classification systems, including MELDB (Kang et al., 2006) and LIPABASE (Messaoudi et al., 2011). Both 
90

91

92

93

94

95

96

97

98

99

100

101

102

103

104

105

106

107

108

109

110

111

112

113

114

115

116

117

118

119

120

121

122

123

124

125

126

127

128

129

130

131

132

133

134

websites have since been deactivated preventing their continued use. The simplicity of the Arpigny and Jeager (1999) classification system is that by providing type proteins for each family, the system can continue to be utilised by the research community. Additional databases such as the Lipase Engineering Database (Pleiss et al., 2000) and ESTHER (Lenfant et al., 2013) classify similar groups of enzymes, however these are not specific to bacterial lipolytic enzymes and as with MELDB and LIPABASE, their continued availability is not guaranteed.

In this paper, the novelty of lipolytic enzymes was confirmed via pairwise sequence comparison to the current type proteins. This allowed us to expand the current classification system and remove spurious claims of novelty and provide a consistent nomenclature to these proteins.

\section{Methods}

\subsection{Literature search}

Multiple methods were used to identify post-1999 claims of novel lipases and lipase families. The key terms 'novel, bacterial, lipase, esterase, carboxylesterase, family' were used to search both the Pubmed (www.ncbi.nlm.nih.gov/pubmed/) and Google scholar (https://scholar.google.de/) databases. Each identified paper was screened to confirm that: (i) the protein was of bacterial/metagenomic origin; (ii) the lipolytic activity of the proposed sequence was confirmed experimentally; (iii) the studied lipolytic protein was indeed novel or assigned to a previously defined family.

\subsection{Sequence comparison}

Type proteins for both the families described by Arpigny and Jaeger (1999) and lipolytic proteins identified by the literature search were compared pairwise via ClustalW (Thompson, Higgins \& Gibson, 1994). Sequence identity was calculated using a python implementation of the "Identity and similarity" tool within the Sequence Manipulation Suite (Stothard, 2000) and has been made available as a reproducible Jupyter notebook (Pairwise_analysis.ipynb) within the Github repository given in the abstract. Proteins were considered likely to be part of the same family at $60 \%$ sequence identity, a threshold that is 3 standard deviations away from the mean similarity between the type proteins of the original 8 families $(30.9 \pm 9.6 \%$ similarity). Proteins identified by sequence comparison to be representatives of the same family had their biochemical properties compared to identify if these were consistent or highly divergent.

Transmembrane regions were detected within each protein using TMHMM (Krogh et al., 2001). Proteins were also annotated with an ESTHER family using the online HMMscan tool, minimum bitscore of 50 (Lenfant et al., 2013), allowing for cross-classification system comparison.

\subsection{Taxonomic occurrence}

To provide insight into the evolutionary diversity or specificity of each family, the NCBI genome database (downloaded November 2017) (Benson et al., 2008) containing 
13572,462 genomes was annotated against the type proteins for each family using BLASTP

136 (Altschul et al., 1990). Matches were separated into two categories: (i) strict matches

137 required high-scoring-pairs to share $>80 \%$ identity across $>80 \%$ of both the query and

138 subject sequences, providing an overall identity of $>64 \%$. Minimum identity of $60 \%$ was

139 selected based on previous research on functional annotation transfer (Radivojac et al.,

140 2013); (ii) An expanded genome search using reduced strictness (>60\% identity across

$141>80 \%$ of the query sequence, resulting in a total identity of $>48 \%$ ) was conducted to

142 provide insight into the potential host range of metagenome-derived proteins with no

143 close matches. The coverage and identity used in the expanded genome search remain

144 more stringent than those previously identified to be optimum for protein family

145 identification and clustering (Veeramachaneni \& Makałowski, 2004). Once annotated,

146 genomes were linked to their taxonomic lineage using the NCBI taxonomy information,

147 implemented in MGkit (Rubino et al., 2014), and the Genome Taxonomy database

148 (GTDB), version 86 (Parks et al., 2018). GTDB annotations were used to confirm the

149

150

151

152

153

154

155

156

157

158

159 taxonomic assignment of genomes when the NCBI assignment was uncertain.

\subsection{Origin check of metagenomic enzymes}

Metagenomic approaches capture both eukaryotic and prokaryotic DNA. To prevent the inclusion of eukaryotic enzymes into this system, enzymes captured by metagenomic approaches were screened against the NCBI genome database. If a strict match was identified, the bacterial origin of the enzyme was assured. For those enzymes without a genome match, possibly due to the host species being as-yet uncultured, the sequences were compared against the NR database using BLASTP. The taxonomic assignment of the top 10 matches was examined and if all were bacterial, the enzyme was included within the classification system, else they were excluded.

\section{Results and discussion}

\subsection{Overview}

Pairwise sequence comparison of the accepted type proteins from Arpigny and Jaeger (1999) to each proposed new family retrieved from the literature identified a single match ( $>60 \%$ similarity), Supplementary Table S1. The HZ lipase proposed by Masomian et al (2016) shared $69.5 \%$ similarity with family 1.5 (U78785) and $57.0 \%$ similarity with family I.6 (M1271) (Masomian et al., 2016). Due to this, the HZ lipase was assigned as a member of family I.5. Choi et al (2004) also proposed a novel lipase (Estl) that was identified to share $62.5 \%$ similarity with family I.6 (M12715), which indicates it is a member of this subfamily.

Pairwise comparison of the proposed families type proteins against one-another was conducted to identify if any families have been discovered multiple times (Supplementary Table S2). We identified that Est30 (Ewis, Abdelal \& Lu, 2004), EstUT1 (Samoylova et al., 2018) and EstOF4 (Rao et al., 2013) share $>60 \%$ similarity, forming a single family, as did EstGtA2 (Charbonneau, Meddeb-Mouelhi \& Beauregard, 2010), bMGL (Kitaura, Suzuki \& Imamura, 2001) and LipS (Chow et al., 2012). 
181

182

183

184

185

186

187

188

189

190

191

192

193

194

195

196

197

198

199

200

201

202

203

204

205

206

207

208

209

210

211

212

213

214

215

216

217

218

219

220

221

222

223

224

225

As this paper aims to act as an expand upon the existing Arpigny and Jaeger (1999) classification system which was updated very recently (Kovacic et al., 2019), all proposed families were included within the existing framework. We remained consistent with the recent update to the original classification system proposed by Kovacic et al (2019), however we propose a few corrections. In the aforementioned update, LipG was identified as the type protein for family $\mathrm{XI}$, however its preference for long-chain fatty acids (C14-16) and activity against triglycerides (tricaprylin) identify it as a true lipase (Lee et al., 2006). Secondly, EstD and LipR were both placed together under family X, however these proteins share $<30.1 \%$ similarity and have different biochemical characteristics, suggesting they represent separate families. This is supported by each proteins catalytic serine being contained within different motifs. Due to this we propose dividing family $X$ into family $X$ and family XXVIII according the numbering proposed in the present study. Finally, in the updated classification system by Kovacic et al, family XVIII was based on EstUT1, separate from Est30 and EstOF4 against which it shares however high $(>60 \%)$ similarity. Due to this we have collapsed family XVIII into family XIII. These changes mean that family I to XIX remain consistent with the published updated classification system, apart from family XI and XVIII. To prevent confusion regarding our changes up to family XIX we have provided descriptions for each family starting at family IX (see Table 1 and individual descriptions provided below).

\subsection{Proposed family I subfamilies}

\subsubsection{Family I, subfamily 9}

LipG, the type protein for family I.9, was isolated during a metagenomic study of korean tidal flat sediment (Lee et al., 2006). The GxSxG motif (where x represents any amino acid) was identified as GHSLG. Genome analysis was unable to find similar proteins within the current genome database (Supplementary Table S3). However, sequence matches within the NR database confirmed its bacterial origin (Supplementary Table S4). Maximum activity was identified against C14 and C16, however activity decreased by $65 \%$ against $\mathrm{C} 18$. Both $\mathrm{Ca}^{2+}$ and $\mathrm{Mn}^{2+}$ were identified to increase the activity of LipG and chelation of divalent metal ions via ethylenediaminetetraacetic acid (EDTA) significantly reduced activity confirming the necessity of metal ions. The effect of temperature and $\mathrm{pH}$ have yet to be reported for LipG. LipG was annotated as belonging to 'Lipase_3' under the ESTHER system.

\subsubsection{Family I, subfamily 10}

RlipE1 was isolated from the rumen of Chinese Holstein cattle using a metagenomic bacterial artificial chromosome (BAC) library (Liu et al., 2009). Whilst no genomes contained similar proteins in our analysis, the closest matches within the NR database were bacterial in origin, indicating that RlipE1 originated from bacteria. The catalytic Serine was identified within GLSMG. Activity against triglycerides along with maximum activity against $\mathrm{C} 16$ confirmed that RlipE1 is a true lipase. Optimum conditions were identified as $30^{\circ} \mathrm{C}$ and $\mathrm{pH} 7-8$. The effect of metal ions has yet to be 
226

227

228

229

230

231

232

233

234

235

236

237

238

239

240

241

242

243

244

245

246

247

248

249

250

251

252

253

254

255

256

257

258

259

260

261

262

263

264

265

266

267

268

269

270

examined. RlipE1 was annotated as 'A85-Feruloyl-Esterase' under the ESTHER system.

\subsubsection{Family I, subfamily 11}

MPlaG is a phospholipase isolated from tidal flat sediment in korea (Lee et al., 2012). The catalytic serine is present within the pentapeptide GHSLG. Activity against triglycerides and a preference for long-chain fatty acids identified MPlaG as a true lipase. Optimum conditions were determined as $\mathrm{pH} 8$ and $25^{\circ} \mathrm{C}$. Addition of $\mathrm{Ca}^{2+}$ increased activity 10 -fold whilst $\mathrm{Cu}^{2+}, \mathrm{Zn}^{2+}$, and $\mathrm{Ni}^{2+}$ all decreased activity. EDTA (5mM) removed all activity, suggesting $\mathrm{Ca}^{2+}$ is essential for activity. Expanded genomic analysis identified possible members of this enzyme family within the Oceanospirillaceae. The source of isolation of MPlaG along with its potential host identified by genome analysis suggest that family I.11 may be specific to the marine environment. MPlaG had no significant match to a ESTHER family.

\subsection{Proposed families}

\subsubsection{Family $X$}

EstD (44.5 kDa) was isolated from Thermotoga maritime (Levisson, van der Oost \& Kengen, 2007), a hyperthermophile isolated from geothermally heated marine sediment (Latif et al., 2013). EstD contains the GHSLG variant of the GxSxG motif. Activity was reduced by $96 \%$ when treated with PMSF. Both highly similar and reduced threshold matches to EstD were specific to the Thermotoga genus. EstD activity increased linearly with temperature to a maximum of $100^{\circ} \mathrm{C}$ at which it has a half life of 1 hour. The optimum pH of EstD was 7 with a maximum activity against C5 to C8. EstD activity is not significantly affected by the presence or absence of metal ions or by treatment with EDTA, suggesting metal ions may have a minor effect but are not essential for activity. EstD was annotated as 'Bacterial_EstLip_FamX' under the ESTHER system.

\subsubsection{Family XI}

The type protein for family XI, EstA (33 kDa) was identified via lipase screening of a bacterial artificial chromosome (BAC) library created using DNA fragments from the South China Sea (Chu et al., 2008). Analysis of EstA and its closest relatives identified the GxSxG variant, GHSMG, within all members. PMSF reduced activity of EstA by $97 \%$. Strict genome analysis was unable to identify any matching sequences but the expanded genome search identified matches were found within 16 taxonomic families and 41 genera. These results suggest that while the exact protein is likely to be present in a uncultured species, variants exist within a diverse range of hosts. EstA is specific for short- and medium-chain fatty acids with maximum activity against C6, decreasing till $\mathrm{C} 10$ past which no activity is detected. The optimum temperature and $\mathrm{pH}$ for EstA was determined to be $45^{\circ} \mathrm{C}$ and 6.5. The metal ions $\mathrm{Mg}^{2+}, \mathrm{Mn}^{2+}$ and $\mathrm{Co}^{2+}$ increase EstA activity while $\mathrm{Fe}^{2+}, \mathrm{Fe}^{3+}$ and $\mathrm{Zn}^{2+}$ reduced activity. The effect of EDTA was not tested. EstA was annotated as belonging to the 'A85-EsteraseD-FGH' family within the ESTHER classification system. 
271

272

273

274

275

276

277

278

279

280

281

282

283

284

285

286

287

288

289

290

291

292

293

294

295

296

297

298

299

300

301

302

303

304

305

306

307

308

309

310

311

312

313

314

315

\subsubsection{Family XIII}

Ewis et al (2004) identified Est30 (30 kDa), the type protein for family XIII, within Geobacillus stearothermophilus ATCC7954 (Ewis, Abdelal \& Lu, 2004). EstUT1, identified by Samoylova et al (2018), was determined to be the second member of this family due to sharing $65 \%$ sequence similarity and key biochemical characteristics (Samoylova et al., 2018). EstOF4 was also identified to be a member of this family based on a protein similarity of $85.6 \%$ and $60.9 \%$ to Est30 and EstUT1 respectively (Rao et al., 2013). The GxSxG motif was identified within all members as GxSLG and treatment with PMSF inhibited enzymatic activity. Optimum conditions for family XIII are $50-80^{\circ} \mathrm{C}$ and $\mathrm{pH} 8-9$. All members were determined to be most active against short and medium-chain fatty acids and display no activity against long-chain fatty acids. EDTA had no effect on either lipases, suggesting activity is independent of metal ions. Strict genome analysis identified the presence of proteins similar to Est30 within four genera (Anoxybacillus, Bacillus, Geobacillus, Parageobacillus) belonging to the Bacillaceae, in which both EstOF4 and EstUT1 was also identified. Expanded genome analysis identified matches in five taxonomic families and 31 genera according to the NCBI taxonomy. This suggests that members of this enzymatic family are present within a wide range of taxonomic groups. All three members of this family were assigned to 'CarbLipBact_1' under the ESTHER classification system.

\subsubsection{Family XVIII}

PlaB, a phospholipase isolated from Legionella pneumophila, is the type protein for family XVIII (Bender et al., 2009). Family XVIII contains its catalytic triad serine within the motif THSTG, replacing the first glycine in the common GxSxG motif with threonine. Genome analysis identified family XVIII as monophyletic to the Legionellaceae, specifically the Legionella and Fluoribacter genera. Due to the clinical relevance of Legionella pneumophila, research on PlaB has focused on its possible role as a virulence factor via hydrolysis of phosphatidylcholine within eukaryotic membranes. PlaB was annotated to its own ESTHER family called 'PlaB'.

\subsubsection{Family $X I X$}

Cultivation of lipase positive isolates from waste-treatment sludge, determined by Rhodamine B-olive oil plates, identified Stenotrophomonas maltophila Psi-1 and the identification of LipSm (40.7 kDa) (Parapouli et al., 2018). LipSm activity was tested against two pNP-bound fatty acids (C4 and $\mathrm{C} 12)$ with maximum activity against $\mathrm{C} 12$. Optimum activity was achieved at $30-40^{\circ} \mathrm{C}$ and $\mathrm{pH} 7$ and all tested metal ions $\left(\mathrm{Ca}^{2+}\right.$, $\mathrm{Mg}^{2+}, \mathrm{Mn}^{2+}, \mathrm{Na}^{2+}$ ) inhibited activity. Sequence analysis identified the presence of the catalytic serine within the pentapeptide GHSQG and similar proteins only in the Stenotrophomonas. The ability of purified LipSm to release free fatty acids from olive oil was not tested, preventing its classification as a true lipase. LipSm was annotated as belonging to the 'Fungal-Bact_LIP' family under the ESTHER classification system.

\subsubsection{Family $X X$}

Peer] reviewing PDF | (2019:05:37278:1:1:NEW 31 May 2019) 
316

317

318

319

320

321

322

323

324

325

326

327

328

329

330

331

332

333

334

335

336

337

338

339

340

341

342

343

344

345

346

347

348

349

350

351

352

353

354

355

356

357

358

359

360

361

Hu et al (2010) isolated two lipolytic enzymes sharing identity with a putative poly(3-hydroxybutyrate) depolymerase, FLS18C and FLS18D ( 32 kDa), from the South China Sea forming the novel family XX (Hu et al., 2010). As biochemical characterisation has only been conducted for FLS18D, it was selected as the type protein. The catalytic serine was identified within the conserved GHSMG motif. Activity was highest against $\mathrm{C} 4$, with decreasing activity until $\mathrm{C} 10$, suggesting preferential hydrolysis of short-chain fatty acids. Optimum activity was achieved at $45^{\circ} \mathrm{C}$ at $\mathrm{pH} 8$. The effect of metal ions on the activity of FLS18D has not yet been studied. Genome analysis was unable to identify similar proteins within any sequenced bacteria but bacterial origin was identified via BLAST annotation against the NR database. Both proteins within this family were annotated as members of the 'Abhydrolase_5' family within ESTHER.

\subsubsection{Family XXI}

Yu et al (2010) identified the type protein, FnL ( 30 kDa), for family XXI within Fervidobacterium nodosum Rt17-B1, an anaerobic thermophile with optimum growth at $80^{\circ} \mathrm{C}$ (Yu et al., 2010). Genome analysis identified FnL as specific to the Fervidobacterium. The pentapeptide sequence AxSxG identified within FnL and its closest relatives in the original analysis. Treatment with PMSF reduced activity to 5\%, confirming $\mathrm{FnL}$ as a serine hydrolase. FnL showed the highest activity towards medium length fatty acids, with highest activity on C10. Whilst initially published as a subfamily of true lipases, its preference to medium-chain fatty acids identifies it as a novel family of non-true lipases. FnL showed the highest activity at $70^{\circ} \mathrm{C}$ and $\mathrm{pH}$ of 9.0 . Activity was significantly affected by metal ion concentrations with significantly reduced activity with $\mathrm{Zn}^{2+}$ and $\mathrm{Cu}^{2+}$ and increased activity with $\mathrm{Mg}^{2+}, \mathrm{Ca}^{2+}, \mathrm{Na}^{+}, \mathrm{Ni}^{2+}$ and $\mathrm{Co}^{2+}$. Chelation using EDTA reduced activity by only $6 \%$, suggesting metal ions are not essential for FnL activity. FnL had no significant match within the ESTHER classification system.

\subsubsection{Family XXII}

Functional analysis of a metagenomic library produced from the rhizosphere microbiome of multiple plants identified EstD2 (53 kDa), the type protein for family XXII (Lee et al., 2010). EstD2 contains the GxSxG motif in the form of GHSQG. Maximum activity was identified against $\mathrm{C} 4$ and decreased as the fatty acid length increased. Optimum conditions were determined to be $35^{\circ} \mathrm{C}$ and $\mathrm{pH} 7-9$. EstD2 activity is highly sensitive to metal ions, as inhibition occurred via addition of $\mathrm{Mn}^{2+}, \mathrm{Zn}^{2+}, \mathrm{Cd}^{2+}, \mathrm{Co}^{2+}$, $\mathrm{Cu}^{2+}, \mathrm{Fe}^{2+}, \mathrm{Ni}^{2+}$ and $\mathrm{Rb}^{2+}$ but not $\mathrm{Ca}^{2+}$ and $\mathrm{Mg}^{2+}$. EDTA reduced activity by up to $68 \%$, indicating that metal ions may be required for activity of family XXII enzymes. No similar proteins were identified within the genome database suggesting this family is present within currently uncultured bacteria, however BLAST annotation against the NCBI-NR database confirmed it as bacterial in origin. EstD2 was annotated as a member of the 'Duf_3089' family within the ESTHER system.

\subsubsection{Family XXIII}

The type protein for family XXIII is LipA (32 kDa) and was identified within a fosmid library created from Brazilian mangrove sediment (Couto et al., 2010). Genome analysis identified no similarity to proteins from sequenced bacteria, however annotation 
362 against the NR database confirmed it as bacterial in origin. LipA has the pentapeptide 363 sequence of AHSMG, fitting with the AxSxG motif. LipA was shown to have the highest 364 activity on $\mathrm{C} 10$ and optimum $\mathrm{pH}$ and temperature of $7.5-8.5$ and $35^{\circ} \mathrm{C}$ respectively. LipA was annotated as belonging to the ESTHER family 'Bacterial_lipase'.

366

367

368

369

370

371

372

373

374

375

376

377

378

379

380

381

382

383

384

385

386

387

388

389

390

391

392

393

394

395

396

397

398

399

400

401

402

403

404

405

406

\subsubsection{Family XXIV}

Rv0045c ( $35.5 \mathrm{kDa})$ is an esterase isolated from Mycobacterium tuberculosis (Guo et al., 2010). The pentapeptide GMSLG contains the catalytic serine. Maximum activity was identified against $\mathrm{C} 6$ and optimum conditions of $39^{\circ} \mathrm{C}$ and $\mathrm{pH} 8$. Genome analysis identified this family of lipolytic enzymes as specific to the Mycobacterium. Crystallography identified that the active site of Rv0045c is highly conserved and consists of only a serine and histidine, not the traditional catalytic triad (Zheng et al., 2011). The reliance of Rv0045c on the active serine has been confirmed by inactivation with PMSF (Ortega et al., 2016). Rv0045c was annotated to the ESTHER family 'Epoxide-hydrolase_like', however similar similarity was identified to multiple other families, suggesting it may represent its own ESTHER family.

\subsubsection{Family XXV}

Analysis of a metagenomic library from a deep-sea sediment for lipolytic activity identified Est3L4 ( 37 kDa), the type protein for family XXV (Jeon et al., 2011). Optimum conditions for activity were identified as $35^{\circ} \mathrm{C}, \mathrm{pH} 7.5$ and $1.5 \mathrm{M} \mathrm{NaCl}$. The addition of $\mathrm{NaCl}$ consistently improved activity, suggesting this family has adapted to the saline environment of the deep-sea. Family $\mathrm{XXV}$ is affected by metal ions as $\mathrm{Mn}^{2+}$, $\mathrm{Mg}^{2+}, \mathrm{Ca}^{2+}, \mathrm{Cu}^{2+}$ significantly increased activity. Reduced activity was identified with addition of $\mathrm{Co}^{2+}$ and addition of $\mathrm{Fe}^{2+}$ inhibited all activity. EDTA was shown to have no effect, suggesting that metal ions are not essential for activity. Addition of PMSF significantly reduced activity. Est3L4 was identified as specific for long-chain fatty acids with maximum activity against $\mathrm{C} 16$. No similar proteins were identified within the genome database. A single transmembrane helix was detected at position 9-31. Est3L4 was annotated as a member of the 'Esterase_phb' ESTHER family.

\subsubsection{Family XXVI}

A metagenomic library of German soil samples identified EstGS (40.7 kDa) containing the GxSxG motif in the form of GHSFG (Nacke et al., 2011). Maximum activity was identified against $\mathrm{C} 6$, with high activity also against $\mathrm{C} 4$. The effect of factors such as temperature, $\mathrm{pH}$ and metal ions were not studied. No matching proteins were identified via genome analysis but bacterial origin was confirmed via annotation against the NCBI-NR database. EstGS was identified as a member of the ESTHER family 'UCP031982'.

\subsubsection{Family XXVII}

Alongside the discovery of family XXVII, Nacke et al (2011) identified the type protein for family XXVII, EstGH (45.6 kDa), via metagenomic analysis of German soil (Nacke et al., 2011). The catalytic serine of EstGH was contained within GHSLG and expanded genome analysis identified similar proteins within the Mycobacterium which is 
407 known to exist within soil samples (Kim et al., 2014). EstGH had no significant match to

408

409

410

411

412

413

414

415

416

417

418

419

420

421

422

423

424

425

426

427

428

429

430

431

432

433

434

435

436

437

438

439

440

441

442

443

444

445

446

447

448

449

450

451

any ESTHER family,

\subsubsection{Family XXVIII}

The high lipolytic activity of Rhodococcus sp. strain CR-53, isolated from soil, led to the discovery of LipR (43 kDa), the type protein for family XXVIII (Bassegoda, Pastor \& Diaz, 2012). LipR was identified to be active against medium length fatty acids with maximum activity against $\mathrm{C} 10$. High activity was determined on Rhodamine-trioleinsupplemented agar plates. Optimum conditions were determined as $40^{\circ} \mathrm{C}$ and $\mathrm{pH} 7$. High concentrations of $\mathrm{Mg}^{2+}, \mathrm{Mn}^{2+}$ and $\mathrm{Ca}^{2+}$ metal ions $(10 \mathrm{mM})$ were shown to increase activity whilst low concentrations $(1 \mathrm{mM})$ of $\mathrm{Fe}^{2+}, \mathrm{Zn}^{2+}, \mathrm{Cu}^{2+}$ and $\mathrm{Ag}^{+}$significantly inhibited the lipolytic activity of LipR. The catalytic serine $\left(\mathrm{Ser}^{212}\right)$ was present within the pentapeptide GYSGG. Family XXVIII was identified to be monophyletic, occurring specifically within members of the genus Rhodococcus. LipR was determined to contain a single transmembrane helix from position 12-34. LipR was annotated as a member of the ESTHER family 'Fungal-Bact_LIP'.

\subsubsection{Family XXIX}

EstGX1 $(22.4 \mathrm{kDa})$ was isolated via metagenomic analysis of high Andean forest soil from Columbia (Jiménez et al., 2012). The catalytic serine was located within the pentapeptide GPSGG. Maximum activity was identified against C4 with optimum conditions of $40^{\circ} \mathrm{C}$ and $\mathrm{pH} 8$. Whilst no genomic match was identified, annotation against NR identified EstGX1 as being bacterial in origin. EstGX1 had no match to any ESTHER family.

\subsubsection{Family XXX}

Metagenomic fosmid analysis of Chinese soil samples identified EstP2K (25 kDa) (Ouyang et al., 2013). Sequence analysis determined the catalytic serine was located within AHSLG and genomic analysis identified no matching sequences. Maximum activity was detected against $\mathrm{C} 8$ with optimum conditions of $45-55^{\circ} \mathrm{C}$ and $\mathrm{pH} 7.5$. Metal ions were identified to have a large effect on the activity of EstP2K with $\mathrm{Mg}^{2+}$ doubling the activity whilst $\mathrm{Co}^{2+}, \mathrm{Cu}^{2+}, \mathrm{Zn}^{2+}, \mathrm{Ca}^{2+}, \mathrm{Pb}^{2+}, \mathrm{Ni}^{2+}, \mathrm{Mn}^{2+}, \mathrm{Hg}^{2+}, \mathrm{Fe}^{2+}$ and $\mathrm{Ag}^{+}$all decreased the activity. Chelation using EDTA halved the enzymatic activity of EstP2K, suggesting $\mathrm{Mg}^{2+}$ is required for activity. Activity was reduced to $1.5 \%$ with the addition of PMSF, confirming EstP2K as a serine hydrolase. EstP2K had a weak match (bitscore = 70.3) to the ESTHER family 'Lipase_2'.

\subsubsection{Family XXXI}

Genome mining of Psychrobacter celer 3Pb1, a known psychrophile, identified the presence of Est12 (35kDa) (Wu et al., 2013). Sequence analysis identified the catalytic serine within GHSAG and genome analysis determined this family as monophyletic to the Psychrobacter. Maximum activity was identified against $\mathrm{C} 4$ with optimum conditions of $35^{\circ} \mathrm{C}$ and $\mathrm{pH} 7-8$. Est12 was identified to retain activity when exposed to high concentrations of $\mathrm{NaCl}(<4.5 \mathrm{M})$ for 13 hours, indicating it is salt tolerant. EDTA was shown to reduce activity by $15 \%$, suggesting metal ions are 
452 beneficial for activity but may not be essential. PMSF completely inactivated Est12

453 when added at $5 \mathrm{mM}$. Est12 was annotated as a member of the 'Hormone-

454 sensitive_lipase_like' family in the ESTHER system.

455

456

457

458

459

460

461

462

463

464

465

466

467

468

469

470

471

472

473

474

475

476

477

478

479

480

481

482

483

484

485

486

487

488

489

490

491

492

493

494

495

496

497

\subsubsection{Family XXXII}

Est9x (32 kDa) was isolated from marine metagenomic library of the South China sea (Fang et al., 2014). Sequence analysis identified the catalytic serine within GHSAG and genome analysis identified highly similar proteins within the Glaciecola, indicating that the original host may have been a member of this genus. PMSF significantly reduced activity, confirming Est9x as a serine hydrolase. Maximum activity was identified against $\mathrm{C} 2$ with decreasing activity till $\mathrm{C} 14$. Optimum conditions were identified as $65^{\circ} \mathrm{C}$ and $\mathrm{pH} 8$. Activity was removed via addition of $\mathrm{Co}^{2+}$ whilst $\mathrm{Ni}^{2+}, \mathrm{Cu}^{2+}$, $\mathrm{Zn}^{2+}$ all decreased activity by $50 \%$ and $\mathrm{Mn}^{2+}$ and $\mathrm{Mg}^{2+}$ only slightly decreased activity. The inability of EDTA to effect the activity of Est9x confirmed it as not being a metalloprotein. Est9x belongs to its own ESTHER family 'Est9X'.

\subsubsection{Family XXXIII}

Bioinformatic analysis of a metagenomic dataset from the Solnechny hot spring in Russia led to the identification of EstDZ2 (29.4 kDa), the type protein for family XXXIII (Zarafeta et al., 2016). EstDZ2 activity was specific for short-chain fatty acids with maximum activity against $\mathrm{C} 4$. Optimum conditions were identified as $55^{\circ} \mathrm{C}$ and $\mathrm{pH} 8$. Metal ions and EDTA were shown to have minimal effect on activity, indicating family XXXIII are not metalloproteins. Sequence analysis identified the catalytic serine within GHSAG and an expanded search identified no similar proteins within the genome database. Activity was significantly reduced by addition of PMSF, confirming its classification as a serine hydrolase. EstDZ2 was annotated as a member of the ESTHER family 'Hormone-sensitive_lipase_like'.

\subsubsection{Family XXXIV}

Est22 (44.56 kDa) was isolated from a metagenomic library of deep-sea sediment. Activity is specific to short length fatty acids as maximum activity was reported against $\mathrm{C} 4$ and no activity occurred past $\mathrm{C} 10$. Optimum conditions were identified as $60^{\circ} \mathrm{C}, \mathrm{pH} 9$ and $0.5 \mathrm{M} \mathrm{NaCl}$. The inability of EDTA to alter Est22 activity suggests that metal ions are not required for activity; hence their effect was not tested. Sequence analysis identified the pentapeptide GPSMG containing the catalytic serine as well as similar proteins being present within the Alteromonadaceae and the expanded search identified additional matches within the Pseudoaltermonadaceae. PMSF was shown to significantly inhibit the activity of Est22. Est22 was identified as belonging to the ESTHER family 'Homoserine_transacetylase'.

\subsubsection{Family XXXV}

The acetyl xylan esterase AcXE2 (25 kDa) was isolated from Caldicellulosiruptor bescii, a highly thermophilic species able to degrade cellulose (Soni et al., 2017). As an acetyl xylan esterase, AcXE2 removes the acetyl group on acetylated xylobiose and glucose. Sequence analysis identified the catalytic serine within the pentapeptide GDSIT. Whilst highly similar enzymes were only identified within the Caldicelulosiruptor,

Peer) reviewing PDF | (2019:05:37278:1:1:NEW 31 May 2019) 
498 potential members of this family were also identified within the Bacillaceae,

499 Chthonomonadaceae and Paenibacillaceae, suggesting a diverse host range. Maximum

500 activity was identified against $\mathrm{C} 2$ and $\mathrm{C} 4$ and optimum temperature of $70^{\circ} \mathrm{C}$ and $\mathrm{pH} 7.5$.

501 AcXE2 had no match to any family within the ESTHER classification system.

502

503

504

505

506

507

508

509

510

511

512

513

514

515

516

517

518

519

520

521

522

523

524

525

526

527

528

529

530

531

532

533

534

535

536

537

538

539

540

541

542

\section{Conclusions}

In this paper, we have significantly expanded the classification of lipolytic enzymes to 35 families and 11 true lipase subfamilies. Defining the biochemical features of each family along with providing type proteins allows for a greater number of potentially novel lipases to be assigned to pre-described families, preventing inconsistency within the literature. The lack of multiple members for each family with proven activity prevented comparative analysis of motifs and biochemical features.

$\mathrm{N}$-terminal single transmembrane alpha-helices were detected within type proteins for 4 families/sub-families. Experimental evidence gained via deletion of the $\mathrm{N}$ terminal transmembrane alpha-helix of LipA identified that this helix lies within the 3D structure of the protein allowing for opening of the lipase cap (Zha et al., 2014). It is likely that the transmembrane alpha-helices detected within the newly described families play a similar role in the structure and functionality of the proteins and do not represent membrane-bound lipases.

Previous research has shown that sequence identity does not guarantee shared functionality (Punta \& Ofran, 2008). The average pairwise similarity between the lipolytic enzymes was $31.3 \%$ with the minimum being $14.2 \%$. Whilst these enzymes do not share identical functionality, they have demonstrated the ability to hydrolyse the release of pNP-bound fatty acids. The low level of sequence similarity between lipolytic enzymes suggests that in vitro examination of proteins sharing low homology with known lipolytic enzymes may lead to identification of additional families.

Cultivation-independent investigation of environmental samples led to the identification and characterisation of multiple lipolytic families suggesting that a greater number of enzymes that have yet to be characterised likely exist. The inability of many families to be assigned to a host via genome search suggests that not only do further lipolytic enzymes remain uncharacterised, but their host species have yet to be cultured. We hope that with the recent increased effort in cultivation of novel species from environmental samples additional enzymes of biotechnological importance will be identified.

\section{Acknowledgements}

We would like to thank Tarek Moustafa and Theresa Streidl for their invaluable feedback during the writing of this manuscript. 
543

544

545

546

547

548

549

550

551

552

553

554

555

556

557

558

559

560

561

562

563

564

565

566

567

568

569

570

571

572

573

574

575

576

577

578

579

580

581

582

583

584

585

586

587

\section{Conflict of interest}

The authors declare no conflict of interest.

\section{Funding information}

TC received funding from the German Research Foundation (DFG) (grant no. CL481/2-1). TCAH received internal funding from the START grant program.

\section{Author contribution}

TCAH performed the analysis and writing with advice and editing provided by TC.

\section{References}

Altschul SF, Gish W, Miller W, Myers EW, Lipman DJ. 1990. Basic local alignment search tool. Journal of Molecular Biology 215:403-410. DOI: 10.1016/s00222836(05)80360-2.

Arpigny JL, Jaeger K-E. 1999. Bacterial lipolytic enzymes: classification and properties. Biochemical Journal 343:177. DOI: 10.1042/0264-6021:3430177.

Bassegoda A, Pastor FIJ, Diaz P. 2012. Rhodococcus sp. strain CR-53 lipr, the first member of a new bacterial lipase family (Family $X$ ) displaying an unusual Y-type oxyanion hole, similar to the Candida antarctica lipase clan. Applied and Environmental Microbiology 78:1724-1732. DOI: 10.1128/AEM.06332-11.

Bender J, Rydzewski K, Broich M, Schunder E, Heuner K, Flieger A. 2009. Phospholipase PlaB of Legionella pneumophila represents a novel lipase family. Protein residues essential for lipolytic activity, substrate specificity and hemolysis. Journal of Biological Chemistry 284:27185-27194. DOI: 10.1074/jbc.M109.026021. Benson DA, Karsch-Mizrachi I, Lipman DJ, Ostell J, Wheeler DL. 2008. GenBank. Nucleic Acids Research 36:25-30. DOI: 10.1093/nar/gkm929.

Canaan S, Maurin D, Chahinian H, Pouilly B, Durousseau C, Frassinetti F, ScappucciniCalvo L, Cambillau C, Bourne Y. 2004. Expression and characterization of the protein Rv1399c from Mycobacterium tuberculosis: A novel carboxyl esterase structurally related to the HSL family. European Journal of Biochemistry 271:39533961. DOI: 10.1111/j.1432-1033.2004.04335.x.

Castilla A, Panizza P, Rodríguez D, Bonino L, Díaz P, Irazoqui G, Rodríguez Giordano S. 2017. A novel thermophilic and halophilic esterase from Janibacter sp. R02, the first member of a new lipase family (Family XVII). Enzyme and Microbial Technology 98:86-95. DOI: 10.1016/j.enzmictec.2016.12.010.

Charbonneau DM, Beauregard M. 2013. Role of Key Salt Bridges in Thermostability of G. thermodenitrificans EstGtA2: Distinctive Patterns within the New Bacterial Lipolytic Enzyme Family XV. PLOS ONE 8:1-18. DOI: 10.1371/journal.pone.0076675.

Charbonneau DM, Meddeb-Mouelhi F, Beauregard M. 2010. A novel thermostable carboxylesterase from Geobacillus thermodenitrificans: Evidence for a new carboxylesterase family. Journal of Biochemistry 148:299-308. DOI: 10.1093/jb/mvq064.

Chow J, Kovacic F, Dall Antonia Y, Krauss U, Fersini F, Schmeisser C, Lauinger B, 
588

589

590

591

592

593

594

595

596

597

598

599

600

601

602

603

604

605

606

607

608

609

610

611

612

613

614

615

616

617

618

619

620

621

622

623

624

625

626

627

628

629

630

631

632

633

Bongen P, Pietruszka J, Schmidt M, Menyes I, Bornscheuer UT, Eckstein M, Thum O, Liese A, Mueller-Dieckmann J, Jaeger KE, Streit WR. 2012. The MetagenomeDerived Enzymes LipS and LipT Increase the Diversity of Known Lipases. PLoS ONE 7. DOI: $10.1371 /$ journal.pone.0047665.

Chu X, He H, Guo C, Sun B. 2008. Identification of two novel esterases from a marine metagenomic library derived from South China Sea. Applied Microbiology and Biotechnology 80:615-625. DOI: 10.1007/s00253-008-1566-3.

Couto GH, Glogauer A, Faoro H, Chubatsu, L.S. SEM, Pedrosa, F.O. 2010. Isolation of a novel lipase from a metagenomic library derived from mangrove sediment from the south Brazilian coast. Genetics and Molecular Research 9:514-523.

Drouault S, Juste C, Marteau P, Renault P, Corthier G. 2002. Oral Treatment with Lactococcus lactis Expressing Staphylococcus hyicus Lipase Enhances Lipid Digestion in Pigs with Induced Pancreatic Insufficiency. 68:3166-3168. DOI: 10.1128/AEM.68.6.3166.

Ewis HE, Abdelal AT, Lu CD. 2004. Molecular cloning and characterization of two thermostable carboxyl esterases from Geobacillus stearothermophilus. Gene 329:187-195. DOI: 10.1016/j.gene.2003.12.029.

Fang Z, Li J, Wang Q, Fang W, Peng H, Zhang X, Xiao Y. 2014. A Novel Esterase from a Marine Metagenomic Library Exhibiting Salt Tolerance Ability. J. Microbiol.

Biotechnol 24:771-780. DOI: 10.4014/jmb.1311.11071.

Glogauer A, Martini VP, Faoro H, Couto GH, Müller-Santos M, Monteiro RA, Mitchell DA, de Souza EM, Pedrosa FO, Krieger N. 2011. Identification and characterization of a new true lipase isolated through metagenomic approach. Microbial Cell Factories 10:54. DOI: 10.1186/1475-2859-10-54.

Guo J, Zheng X, Xu L, Liu Z, Xu K, Li S, Wen T, Liu S, Pang H. 2010. Characterization of a Novel Esterase Rv0045c from Mycobacterium tuberculosis. PLOS ONE 5. DOI: 10.1371/journal.pone.0020506.

Handrick R, Reinhardt S, Focarete ML, Scandola M, Adamus G, Kowalczuk M, Jendrossek D. 2001. A New Type of Thermoalkalophilic Hydrolase of Paucimonas lemoignei with High Specificity for Amorphous Polyesters of Short Chain-length Hydroxyalkanoic Acids. Journal of Biological Chemistry 276:36215-36224. DOI: 10.1074/jbc.M101106200.

Hu Y, Fu C, Huang Y, Yin Y, Cheng G, Lei F, Lu NA, Li J, Ashforth EJ, Zhang L, Zhu B. 2010. Novel lipolytic genes from the microbial metagenomic library of the South China Sea marine sediment. FEMS Microbiology Ecology 72:228-237. DOI: 10.1111/j.1574-6941.2010.00851.x.

Jaeger KE, Eggert T. 2002. Lipases for biotechnology. Current Opinion in Biotechnology 13:390-397. DOI: 10.1016/S0958-1669(02)00341-5.

Jeon JH, Kim JT, Lee HS, Kim SJ, Kang SG, Choi SH, Lee J-H. 2011. Novel lipolytic enzymes identified from metagenomic library of deep-sea sediment. Evidencebased Complementary and Alternative Medicine 2011. DOI: 10.1155/2011/271419.

Jiménez DJ, Montaña JS, Álvarez D, Baena S. 2012. A novel cold active esterase derived from Colombian high Andean forest soil metagenome. World Journal of Microbiology and Biotechnology 28:361-370. DOI: 10.1007/s11274-011-0828-x.

Kang HY, Kim JF, Kim MH, Park SH, Oh TK, Hur CG. 2006. MELDB: A database for microbial esterases and lipases. FEBS Letters 580:2736-2740. DOI:

Peer) reviewing PDF | (2019:05:37278:1:1:NEW 31 May 2019) 
634

635

636

637

638

639

640

641

642

643

644

645

646

647

648

649

650

651

652

653

654

655

656

657

658

659

660

661

662

663

664

665

666

667

668

669

670

671

672

673

674

675

676

677

678

679

10.1016/j.febslet.2006.04.034.

Kim EY, Oh KH, Lee MH, Kang CH, Oh TK, Yoon JH. 2009. Novel cold-adapted alkaline lipase from an intertidal flat metagenome and proposal for a new family of bacterial lipases. Applied and Environmental Microbiology 75:257-260. DOI: 10.1128/AEM.01400-08.

Kim Y-E, Yoon H, Kim M, Nam Y-J, Kim H, Seo Y, Lee G-M, Ja Kim Y, Kong W-S, Kim J-G, Seu Y-B. 2014. Metagenomic analysis of bacterial communities on Dokdo Island. The Journal of General and Applied Microbiology 60:65-74. DOI: 10.2323/jgam.60.65.

Kitaura S, Suzuki K, Imamura S. 2001. Monoacylglycerol lipase from moderately thermophilic Bacillus sp. Strain H-257: Molecular cloning, sequencing, and expression in Escherichia coli of the gene. Journal of Biochemistry 129:397-402. DOI: 10.1093/oxfordjournals.jbchem.a002870.

Kovacic F, Babic N, Krauss U, Jaeger K. 2019. Classification of Lipolytic Enzymes from Bacteria. In: Aerobic Utilization of Hydrocarbons, Oils and Lipids. Chapter 24. DOI: 10.1007/978-3-319-39782-5.

Krogh A, Larsson B, Von Heijne G, Sonnhammer ELL. 2001. Predicting transmembrane protein topology with a hidden Markov model: Application to complete genomes. Journal of Molecular Biology 305:567-580. DOI: 10.1006/jmbi.2000.4315.

Latif H, Lerman JA, Portnoy VA, Tarasova Y, Nagarajan H, Schrimpe-Rutledge AC, Smith RD, Adkins JN, Lee DH, Qiu Y, Zengler K. 2013. The Genome Organization of Thermotoga maritima Reflects Its Lifestyle. PLoS Genetics 9. DOI: 10.1371/journal.pgen.1003485.

Lee MH, Hong KS, Malhotra S, Park JH, Hwang EC, Choi HK, Kim YS, Tao W, Lee SW. 2010. A new esterase EstD2 isolated from plant rhizosphere soil metagenome. Applied Microbiology and Biotechnology 88:1125-1134. DOI: 10.1007/s00253-0102729-6.

Lee MH, Lee CH, Oh TK, Song JK, Yoon JH. 2006. Isolation and characterization of a novel lipase from a metagenomic library of tidal flat sediments: Evidence for a new family of bacterial lipases. Applied and Environmental Microbiology 72:7406-7409. DOI: 10.1128/AEM.01157-06.

Lee MH, Oh KH, Kang CH, Kim JH, Oh TK, Ryu CM, Yoon JH. 2012. Novel metagenome-derived, cold-adapted alkaline phospholipase with superior lipase activity as an intermediate between phospholipase and lipase. Applied and Environmental Microbiology 78:4959-4966. DOI: 10.1128/AEM.00260-12.

Lenfant N, Hotelier T, Velluet E, Bourne Y, Marchot P, Chatonnet A. 2013. ESTHER, the database of the $\alpha / \beta$-hydrolase fold superfamily of proteins: Tools to explore diversity of functions. Nucleic Acids Research 41:423-429. DOI: 10.1093/nar/gks1154.

Levisson M, van der Oost J, Kengen SWM. 2007. Characterization and structural modeling of a new type of thermostable esterase from Thermotoga maritima. FEBS Journal 274:2832-2842. DOI: 10.1111/j.1742-4658.2007.05817.x.

Liu K, Wang J, Bu D, Zhao S, McSweeney C, Yu P, Li D. 2009. Isolation and biochemical characterization of two lipases from a metagenomic library of China Holstein cow rumen. Biochemical and Biophysical Research Communications 385:605-611. DOI: 10.1016/j.bbrc.2009.05.110. 
680

681

682

683

684

685

686

687

688

689

690

691

692

693

694

695

696

697

698

699

700

701

702

703

704

705

706

707

708

709

710

711

712

713

714

715

716

717

718

719

720

721

722

723

724

725

Masomian M, Abd Rahman RNZR, Salleh AB, Basri M. 2016. Analysis of comparative sequence and genomic data to verify phylogenetic relationship and explore a new subfamily of bacterial lipases. PLOS ONE 11:1-20. DOI: 10.1371/journal.pone.0149851.

Messaoudi A, Belguith H, Ghram I, Hamida J Ben. 2011. LIPABASE: a database for "true" lipase family enzymes. International Journal of Bioinformatics Research and Applications 7:390. DOI: 10.1504/IJBRA.2011.043770.

Nacke H, Will C, Herzog S, Nowka B, Engelhaupt M, Daniel R. 2011. Identification of novel lipolytic genes and gene families by screening of metagenomic libraries derived from soil samples of the German Biodiversity Exploratories. FEMS Microbiology Ecology 78:188-201. DOI: 10.1111/j.1574-6941.2011.01088.x.

Ortega C, Anderson LN, Frando A, Sadler NC, Brown RW, Smith RD, Wright AT, Grundner C. 2016. Systematic Survey of Serine Hydrolase Activity in Mycobacterium tuberculosis Defines Changes Associated with Persistence. Cell Chemical Biology 23:290-298. DOI: 10.1016/j.chembiol.2016.01.003.

Ouyang LM, Liu JY, Qiao M, Xu JH. 2013. Isolation and biochemical characterization of two novel metagenome-derived esterases. Applied Biochemistry and Biotechnology 169:15-28. DOI: 10.1007/s12010-012-9949-4.

Parapouli M, Foukis A, Stergiou PY, Koukouritaki M, Magklaras P, Gkini OA, Papamichael EM, Afendra AS, Hatziloukas E. 2018. Molecular, biochemical and kinetic analysis of a novel, thermostable lipase (LipSm) from Stenotrophomonas maltophilia Psi-1, the first member of a new bacterial lipase family (XVIII). Journal of Biological Research (Greece) 25:1-12. DOI: 10.1186/s40709-018-0074-6.

Parks DH, Chuvochina M, Waite DW, Rinke C, Skarshewski A, Chaumeil P, Hugenholtz P, Skarsgewski A. 2018. A standardized bacterial taxonomy based on genome phylogeny substantially revises the tree of life. bioRxiv:256800. DOI: 10.1101/256800.

Pleiss J, Fischer M, Peiker M, Thiele C, Schmid RD. 2000. Lipase engineering database: Understanding and exploiting sequence-structure-function relationships. Journal of Molecular Catalysis - B Enzymatic 10:491-508. DOI: 10.1016/S13811177(00)00092-8.

Punta M, Ofran Y. 2008. The rough guide to in silico function prediction, or how to use sequence and structure information to predict protein function. PLoS Computational Biology 4. DOI: 10.1371/journal.pcbi.1000160.

Radivojac P, Clark WT, Oron TR, Schnoes AM, Wittkop T, Sokolov A, Graim K, Funk C, Verspoor K, Ben-Hur A, Pandey G, Yunes JM, Talwalkar AS, Repo S, Souza ML, Piovesan D, Casadio R, Wang Z, Cheng J, Fang H, Gough J, Koskinen P, Törönen P, Nokso-Koivisto J, Holm L, Cozzetto D, Buchan DWA, Bryson K, Jones DT, Limaye B, Inamdar H, Datta A, Manjari SK, Joshi R, Chitale M, Kihara D, Lisewski AM, Erdin S, Venner E, Lichtarge O, Rentzsch R, Yang H, Romero AE, Bhat P, Paccanaro A, Hamp T, Kaßner R, Seemayer S, Vicedo E, Schaefer C, Achten D, Auer F, Boehm A, Braun T, Hecht M, Heron M, Hönigschmid P, Hopf TA, Kaufmann S, Kiening M, Krompass D, Landerer C, Mahlich Y, Roos M, Björne J, Salakoski T, Wong A, Shatkay H, Gatzmann F, Sommer I, Wass MN, Sternberg MJE, Škunca N, Supek F, Bošnjak M, Panov P, Džeroski S, Šmuc T, Kourmpetis YAI, Van Dijk ADJ, Ter Braak CJF, Zhou Y, Gong Q, Dong X, Tian W, Falda M, 
726

727

728

729

730

731

732

733

734

735

736

737

738

739

740

741

742

743

744

745

746

747

748

749

750

751

752

753

754

755

756

757

758

759

760

761

762

763

764

765

766

767

768

769

770

771

Fontana P, Lavezzo E, Di Camillo B, Toppo S, Lan L, Djuric N, Guo Y, Vucetic S, Bairoch A, Linial M, Babbitt PC, Brenner SE, Orengo C, Rost B, Mooney SD, Friedberg I. 2013. A large-scale evaluation of computational protein function prediction. Nature Methods 10:221-227. DOI: 10.1038/nmeth.2340.

Rao L, Xue Y, Zheng Y, Lu JR, Ma Y. 2013. A Novel Alkaliphilic Bacillus Esterase Belongs to the 13th Bacterial Lipolytic Enzyme Family. PLoS ONE 8. DOI: 10.1371/journal.pone.0060645.

Rao L, Xue Y, Zhou C, Tao J, Li G, Lu JR, Ma Y. 2011. A thermostable esterase from Thermoanaerobacter tengcongensis opening up a new family of bacterial lipolytic enzymes. Biochimica et Biophysica Acta - Proteins and Proteomics 1814:16951702. DOI: 10.1016/j.bbapap.2011.08.013.

Rubino F, Mccabe MS, Newbold J, Veneman JB, Creevey CJ. 2014.MGkit: Metagenomic Framework For The Study Of Microbial Communities communities from a taxonomic and functional perspective, little has Rationale analysis of metagenomic data that includes fully automated analysis and carry out statistical tests to iden

Samoylova Y V., Sorokina KN, Romanenko M V., Parmon VN. 2018. Cloning, expression and characterization of the esterase estUT1 from Ureibacillus thermosphaericus which belongs to a new lipase family XVIII. Extremophiles 22:271-285. DOI: 10.1007/s00792-018-0996-9.

Soni S, Sathe SS, Odaneth AA, Lali AM, Chandrayan SK. 2017. SGNH hydrolase-type esterase domain containing Cbes-AcXE2: a novel and thermostable acetyl xylan esterase from Caldicellulosiruptor bescii. Extremophiles 21:687-697. DOI: 10.1007/s00792-017-0934-2.

Sorokin DY, Jones BE. 2009. Improved method for direct screening of true lipaseproducing microorganisms with particular emphasis on alkaline conditions. Microbiology 78:125-130. DOI: 10.1134/S0026261709010160.

Stothard P. 2000. The Sequence Manipulation Suite: javascript programs for analysing and formating protein and DNA sequences. Biotechniques 28:1102-1104. DOI: 10.7939/R3FQ9QK0V.

Thompson JD, Higgins DG, Gibson TJ. 1994. CLUSTAL W: Improving the sensitivity of progressive multiple sequence alignment through sequence weighting, positionspecific gap penalties and weight matrix choice. Nucleic Acids Research 22:46734680. DOI: 10.1093/nar/22.22.4673.

Veeramachaneni V, Makałowski W. 2004. Visualizing sequence similarity of protein families. Genome Research 14:1160-1169. DOI: 10.1101/gr.2079204.

Wu G, Zhang S, Zhang H, Zhang S, Liu Z. 2013. A novel esterase from a psychrotrophic bacterium Psychrobacter celer 3Pb1 showed cold-adaptation and salt-tolerance. Journal of Molecular Catalysis B: Enzymatic 98:119-126. DOI: 10.1016/j.molcatb.2013.10.012.

Yu S, Yu S, Han W, Wang H, Zheng B, Feng Y. 2010. A novel thermophilic lipase from Fervidobacterium nodosum Rt17-B1 representing a new subfamily of bacterial lipases. Journal of Molecular Catalysis B: Enzymatic 66:81-89. DOI: 10.1016/j.molcatb.2010.03.007.

Zarafeta D, Moschidi D, Ladoukakis E, Gavrilov S, Chrysina ED, Chatziioannou A, Kublanov I, Skretas G, Kolisis FN. 2016. Metagenomic mining for thermostable

Peer] reviewing PDF | (2019:05:37278:1:1:NEW 31 May 2019) 
772 esterolytic enzymes uncovers a new family of bacterial esterases. Scientific 773 Reports 6:1-16. DOI: 10.1038/srep38886.

774 Zha D, Zhang H, Zhang H, Xu L, Yan Y. 2014. N-terminal transmembrane domain of 775 lipase LipA from Pseudomonas protegens Pf-5: A must for its efficient folding into 776 an active conformation. Biochimie 105:165-171. DOI:

$777 \quad$ 10.1016/j.biochi.2014.07.007.

778 Zheng X, Guo J, Xu L, Li H, Zhang D, Zhang K, Sun F, Wen T, Liu S, Pang H. 2011.

779

780 Crystal structure of a novel esterase RV0045c from mycobacterium tuberculosis.

781 PLOS ONE 6. DOI: 10.1371/journal.pone.0020506. 


\section{Table 1 (on next page)}

Bacterial lipolytic enzyme families.

Table summerising each bacterial lipolytic family. Each family is provided with a type protein for which the accession number and name is provided along with its proposed function. The original publication in which each family was integrated into the classification system is stated. 


\begin{tabular}{|c|c|c|c|c|c|}
\hline Family & $\begin{array}{l}\text { Sub- } \\
\text { family }\end{array}$ & $\begin{array}{l}\text { Type } \\
\text { protein }\end{array}$ & Publication & Accession & Function \\
\hline \multirow[t]{11}{*}{ Family I } & 1 & & $\begin{array}{l}\text { Arpigny and } \\
\text { Jaeger } \\
\text { (1999) }\end{array}$ & D50587 & True lipase \\
\hline & 2 & & $\begin{array}{l}\text { Arpigny and } \\
\text { Jaeger } \\
\text { (1999) }\end{array}$ & X70354 & True lipase \\
\hline & 3 & & $\begin{array}{l}\text { Arpigny and } \\
\text { Jaeger } \\
\text { (1999) }\end{array}$ & D11455 & True lipase \\
\hline & 4 & & $\begin{array}{l}\text { Arpigny and } \\
\text { Jaeger } \\
\text { (1999) }\end{array}$ & M74010 & True lipase \\
\hline & 5 & & $\begin{array}{l}\text { Arpigny and } \\
\text { Jaeger } \\
\text { (1999) }\end{array}$ & U78785 & True lipase \\
\hline & 6 & & $\begin{array}{l}\text { Jaeger and } \\
\text { Eggert } \\
(2002)\end{array}$ & M12715 & $\begin{array}{l}\text { True lipase / } \\
\text { Phospholipase }\end{array}$ \\
\hline & 7 & & $\begin{array}{l}\text { Jaeger and } \\
\text { Eggert } \\
(2002)\end{array}$ & X99255 & True lipase \\
\hline & 8 & Lip1 & This paper & Q3IF07 & True lipase \\
\hline & 9 & LipG & This paper & DQ458963 & True lipase \\
\hline & 10 & RlipE1 & This paper & FJ529693 & - \\
\hline & 11 & MPlaG & This paper & EU285670 & $\begin{array}{l}\text { True lipase / } \\
\text { Phospholipase }\end{array}$ \\
\hline Family II & & & $\begin{array}{l}\text { Arpigny and } \\
\text { Jaeger } \\
\text { (1999) }\end{array}$ & P10480 & $\begin{array}{l}\text { Secreted } \\
\text { acyltranferase }\end{array}$ \\
\hline Family III & & & $\begin{array}{l}\text { Arpigny and } \\
\text { Jaeger } \\
\text { (1999) }\end{array}$ & M86351 & $\begin{array}{l}\text { Extracellular } \\
\text { lipase }\end{array}$ \\
\hline Family IV & & & $\begin{array}{l}\text { Arpigny and } \\
\text { Jaeger } \\
\text { (1999) }\end{array}$ & X62835 & Esterase \\
\hline Family V & & & $\begin{array}{l}\text { Arpigny and } \\
\text { Jaeger } \\
\text { (1999) }\end{array}$ & M58445 & $\begin{array}{l}\text { PHA- } \\
\text { depolymerase }\end{array}$ \\
\hline Family VI & & & $\begin{array}{l}\text { Arpigny and } \\
\text { Jaeger } \\
\text { (1999) }\end{array}$ & D90904 & $\begin{array}{l}\text { Carboxylesteras } \\
\text { es }\end{array}$ \\
\hline Family VII & & & $\begin{array}{l}\text { Arpigny and } \\
\text { Jaeger } \\
\text { (1999) }\end{array}$ & Q01470 & $\begin{array}{l}\text { Carbamate } \\
\text { hydrolase }\end{array}$ \\
\hline Family VIII & & & Arpigny and & AAA99492 & Stereoselective \\
\hline
\end{tabular}




\begin{tabular}{|c|c|c|c|c|}
\hline & & $\begin{array}{l}\text { Jaeger } \\
(1999)\end{array}$ & & esterase \\
\hline Family IX & phaZ7 & $\begin{array}{l}\text { Kovacic et al } \\
\text { (2019) }\end{array}$ & AY026355 & $\begin{array}{l}\text { Poly(3- } \\
\text { hydroxylbutyrate } \\
\text { ) depolymerase }\end{array}$ \\
\hline Family X & EstD & This paper & NP_228147 & $\begin{array}{l}\text { Carboxylesteras } \\
\text { e }\end{array}$ \\
\hline Family XI & EstA & This paper & ABY60416 & Esterase \\
\hline Family XII & LipEH166 & & EU515239 & Lipase \\
\hline Family XIII & Est30 & This paper & AY186197 & $\begin{array}{l}\text { Carboxylesteras } \\
\text { e }\end{array}$ \\
\hline Family XIV & EstA3 & $\begin{array}{l}\text { Kovacic et al } \\
\text { (2019) }\end{array}$ & NP_623858 & $\begin{array}{l}\text { Carboxylesteras } \\
\text { e }\end{array}$ \\
\hline Family XV & EstGtA2 & $\begin{array}{l}\text { Kovacic et al } \\
(2019)\end{array}$ & AEN92268 & $\begin{array}{l}\text { Carboxylesteras } \\
\text { e }\end{array}$ \\
\hline Family XVI & LipSM54 & $\begin{array}{l}\text { Kovacic et al } \\
(2019)\end{array}$ & AGF29555 & Lipase \\
\hline $\begin{array}{l}\text { Family } \\
\text { XVII }\end{array}$ & LipJ2 & $\begin{array}{l}\text { Kovacic et al } \\
\text { (2019) }\end{array}$ & KX096709 & Lipase \\
\hline $\begin{array}{l}\text { Family } \\
\text { XVIII }\end{array}$ & plaB & This paper & EF408871 & $\begin{array}{l}\text { Phosphatidylchol } \\
\text { ine-specific } \\
\text { phospholipase }\end{array}$ \\
\hline Family XIX & LipSM & $\begin{array}{l}\text { Kovacic et al } \\
\text { (2019) }\end{array}$ & KX353755 & Lipase \\
\hline Family XX & FLS18D & This paper & ACL67852 & Esterase \\
\hline Family XXI & FnL & This paper & ABS61180 & Lipase \\
\hline $\begin{array}{l}\text { Family } \\
\text { XXII }\end{array}$ & EstD2 & This paper & GQ866023 & $\begin{array}{l}\text { Secreted } \\
\text { esterase }\end{array}$ \\
\hline $\begin{array}{l}\text { Family } \\
\text { XXIII }\end{array}$ & LipA & This paper & ACJ13070 & Lipase \\
\hline $\begin{array}{l}\text { Family } \\
\text { XXIV }\end{array}$ & Rv0045c & This paper & NP_214559 & Esterase \\
\hline $\begin{array}{l}\text { Family } \\
\text { XXV }\end{array}$ & EM3L4 & This paper & GQ340926 & Lipase \\
\hline $\begin{array}{l}\text { Family } \\
\text { XXVI }\end{array}$ & EstGS & This paper & HQ156900 & $\begin{array}{l}\text { Secreted } \\
\text { esterase }\end{array}$ \\
\hline $\begin{array}{l}\text { Family } \\
\text { XXVII }\end{array}$ & EstGH & This paper & HQ156914 & Esterase \\
\hline $\begin{array}{l}\text { Family } \\
\text { XXVIII }\end{array}$ & LipR & This paper & YP_345621 & Lipase \\
\hline $\begin{array}{l}\text { Family } \\
\text { XXIX }\end{array}$ & EstGX1 & This paper & HQ262952 & Lipase \\
\hline $\begin{array}{l}\text { Family } \\
\text { XXX }\end{array}$ & EstP2K & This paper & JN001203 & Esterase \\
\hline $\begin{array}{l}\text { Family } \\
\text { XXXI }\end{array}$ & Est12 & This paper & KF313138 & Esterase \\
\hline $\begin{array}{l}\text { Family } \\
\text { XXXII }\end{array}$ & Est9x & This paper & AFR79233 & Lipase \\
\hline $\begin{array}{l}\text { Family } \\
\text { XXXIII }\end{array}$ & EstDZ2 & This paper & KX301277 & $\begin{array}{l}\text { Secreted } \\
\text { carboxylesterase }\end{array}$ \\
\hline
\end{tabular}




\begin{tabular}{l|llll|}
\cline { 2 - 5 } $\begin{array}{l}\text { Family } \\
\text { XXXIV } \\
\text { Family } \\
\text { XXXV }\end{array}$ & Est22 & This paper & GAC12013 & $\begin{array}{l}\text { Homoserine } \\
\text { transacetylase }\end{array}$ \\
\hline & AcXE2 & This paper & ACM59679 & $\begin{array}{l}\text { Acetyl xylan } \\
\text { esterase }\end{array}$ \\
\hline
\end{tabular}

